\title{
RANCANG BANGUN APLIKASI PEMESANAN KUE BERBASIS MOBILE PADA TOKO KUE PRIMADONA
}

\section{(Design and Develop Application of Mobile Base Cake Order Case of Primadona Cake Store)}

\author{
Rojiman Hadisaputra, Nadiyasari Agitha*, Moh. Ali Albar \\ Program Studi Teknik Informatika, Fakultas Teknik, Universitas Mataram \\ JI. Majapahit 62, Mataram, Lombok NTB, INDONESIA \\ Email: rojiman@gmail.com, nadiya@unram.ac.id,mohalialbar@unram.ac.id
}

\begin{abstract}
The development of technology affects the society in industry, either big or small scale of the industry. In Mataram city, there are a lot of businesses that have utilized technology to improve their businesses. The technology usually used is a smartphone. A smartphone chose because it's mobility and easiness to use. Although smartphone technology has been used widely, there are some businesses which do not have information system and still use the manual system in their business operation. One of them is UD. Primadonna's cake shop. Therefore it is important to assist them by designing a mobile-based order application. The method used is a waterfall, which consists of several steps in its design, including analysis of system requirement, designing, implementation, testing, and maintenance. For the database, XAMPP used as a server and PHP used to connect with the mobile application that will build by using ionic framework. The result from the black box testing shows that all features work well. Meanwhile, the questionnaire of 30 respondents reveals that mean value for all question is 3.85. Hence, it can be concluded that the order application designed is good and work well.
\end{abstract}

Keywords: Technology, Store, Smartphone Waterfall, Ionic, MOS

*Penulis Korespondensi

\section{Pendahuluan}

Teknologi telah menjadi kebutuhan primer yang mendampingi kebutuhan manusia saat ini. Pemanfaatan teknologi informasi tentunya mempermudah aktivitas dalam berbagai bidang, salah satunya bisnis atau usaha. Pemanfaatan teknologi dalam bidang bisnis membuat bisnis semakin berkembang tidak hanya bagi perusahaan besar namun juga usaha kecil menengah. Penggunaan teknologi dalam melakukan jual beli dapat dimanfaatkan sehingga meningkatkan keuntungan perusahaan [1].

Beberapa hal yang bisa ditingkatkan dengan pemanfaatan teknologi seperti memberikan informasi kepada pembeli tentang suatu usaha, transaksi jual beli yang lebih cepat dan akurat. Saat ini, kebanyakan tempat usaha di berbagai daerah yang mulai menerapkan penggunaan teknologi dalam usahanya, khususnya di Kota Mataram. Teknologi yang akan digunakan adalah smartphone. Disebabkan mobilitas serta kemudahan dalam penggunaannya, penggunaan aplikasi bergerak dapat dimanfaatkan oleh UD Primadona untuk meningkatkan usahanya. Penggunaan perangkat bergerak yang dapat tehubung menggunakan jaringan mengalami peningkatan. Saat ini, kurang lebih sembilan juta orang menggunakan ponsel untuk mengakses internet. Total pengguna semakin signifikan karena harga dari perangkat bergerak semakin murah [2].

Dalam melakukan pemasaran UD Primadona masih menggunakan cara tradisional yaitu harus bertemu secara langsung. Pemasaran ini menghambat peluang untuk masuk ke kalangan milenial, dimana segala kegiatan dilakukan dengan menggunakan smartphone. Berdasarkan permasalahan ini, UD Primadona melakukan inovasi dengan menggunakan aplikasi yang dibuat menggunakan sistem operasi Android. Aplikasi ini akan membantu memperluas pasar yang dimiliki UD Primadona.

\section{TinjauAn PUSTAKa}

Pada pembuatan aplikasi berbasis Android untuk Catering di Cimahi, Jawa Barat, terdapat permasalahan dalam pemesanan yang memerlukan banyak waktu. Aplikasi yang dibuat mencakup penyelesaian masalah tersebut, diantaranya dengan membuat aplikasi berdasarkan metode extreme programming. Basis Android digunakan untuk pembuatan programnya dan 
menggunakan tempat penyimpanan mySql. Aplikasi yang dibuat mendapatkan hasil berdasarkan user acceptance test yaitu sebesar 85\% [3].

Sebuah aplikasi yang dinamakan Fonde pada pemesanan makanan melalui media sosial dan dapat melakukan pelacakan pada pengiriman makanan yang telah dipesan. Aplikasi ini dibangun dengan menggunakan aplikasi Android Studio. Metode pembuatan aplikasi adalah waterfall. Berdasarkan pengujian yang dilakukan, tingkat kepuasan pelanggan menggunakan aplikasi berdasarkan kuesioner didapatkan hasil $86,7 \%$. Sedangkan tingkat kepuasan menggunakan media sosial dengan hasil $75,4 \%$. Berdasarkan hasil kuesioner, pelanggan dinyatakan puas dengan aplikasi maupun fitur yang terdapat dalam aplikasi Fonde [4].

Pada penelitian Aplikasi penjualan kue kering berbasis web untuk industri rumahan Winda, terdapat beberapa masalah yang mendasar yaitu banyaknya pesanan perbulan serta banyaknya reseller yang ikut menjual kue produksi Winda. Pembuatan aplikasi menggunakan Bahasa pemrograman HTML, PHP dan MySQL sehingga lebih mudah untuk melakukan pemesanan kue kering. Aplikasi ini membantu industri rumahan Winda dalam menerima pesanan dan menyalurkannya melalui reseller yang telah terdaftar [5].

Aplikasi pemesanan makanan ringan pada UD Enggal Jaya Semarang dibuat untuk mempermudah pemasaran pada UD tersebut. Pemasaran yang dilakukan masih sederhana yaitu dengan datang langsung ke lokasi Toko. Pembuatan aplikasi menggunakan metode Waterfall, arsitektur perancangan menggunakan UML, aplikasi program menggunakan Android studio dan database MySQL. Aplikasi tersebut menghasilkan sebuah sistem yang dapat memudahkan UD Enggal Jaya Semarang untuk dapat memasarkan melalui media online [6].

Pada penelitian di Toko Faisal Collection yang merupakan sebuah toko yang menjual barang jadi yaitu pakaian pria dan wanita dengan sistem ecer, lusin maupun kodi, membutuhkan aplikasi untuk membantu penjualannya. Aplikasi yang dibuat menggunakan metode prototyping dan aplikasi program menggunakan Android studio. Aplikasi ini membantu Toko Faisal Collection untuk menjaring pelanggan baru maupun pelanggan lama untuk dapat lebih mudah dalam bertransaksi [7].

Pengertian Informasi menurut Jogiyanto yang dikutip oleh Machmud (2013) adalah sebagai berikut: Informasi adalah data yang dapat dirubah bentuk menjadi lebih berguna untuk yang akan menggunakannya [8].

Sistem informasi didefinisikan dengan menjadikan satu kesatuan, melakukan proses, melakukan penyimpanan, melakukan analisa, serta menyebarkan informasi untuk tujuan tertentu [9].

Android merupakan sistem operasi bebasis linux yang dapat dipergunakan hanya untuk perangkat bergerak seperti smartphone atau tablet. Sistem operasi android bersifat open source sehingga para programmer dapat dengan mudah membangun sistem [10].

Ionic merupakan frame work aplikasi hybrid yang terintegrasi dengan angular dimana ionic merupakan kumpulan program yang siap pakai. Konsep dasar dari ionic adalah MVC (Model, View, Controller) walaupun dengan cara yang sedikit berbeda dari frame work yang lain seperti $\mathrm{Cl}$ [11].

\section{Metode Penelitian}

Metode yang digunakan dalam merancang aplikasi ini adalah waterfall.

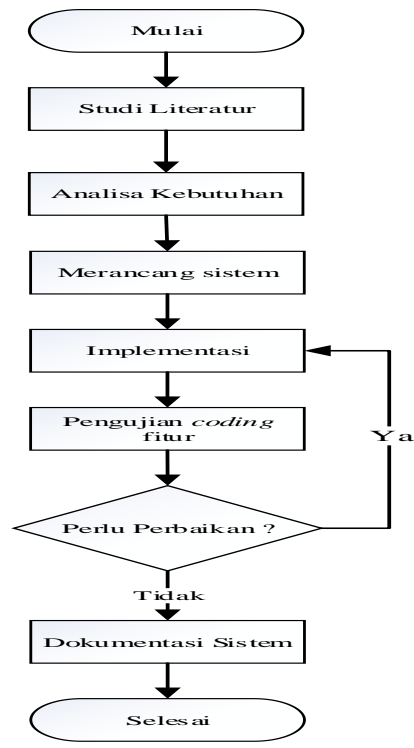

Gambar 1 Metode waterfall

Analisa kebutuhan dilakukan untuk mengetahui kebutuhan sistem yang akan dibangun, Analisa mulai dari kebutuhan user untuk bisa memesan kue secara cepat dan mudah, kemudian kebutuhan admin untuk bisa mengelola data yang digunakan dalam sistem.

\subsection{Kondisi Saat ini}

Proses pemesanan kue pada toko primadona saat ini masih menggunakan cara tradisional dimana ini dirasa kurang efektif dan memakan banyak waktu, 
dalam hal pembukuan juga kurang efektif untuk proses evaluasi maupun pengambilan keputusan kedepannya.

\subsection{Sistem yang akan dibangun}

Sistem yang akan dibangun adalah sistem pemesanan berbasis mobile, dimana user ataupun pelanggan bisa mengakses data maupun memesan kue melalui smartphone yang memudahkan dan mempercepat prosesnya. Untuk admin tetap menggunakan web untuk pengelolaan datanya.

\subsection{Kelebihan yang dimiliki sistem}

Kelebihan dari sistem yang akan dibangun dibandingkan dengan sistem sebelumnya sebagai berikut :

a. Sistem bisa melakukan pemesanan kue secara online melalui smartphone.

b. Sistem dapat menampilkan daftar kue secara lebih menarik dan lebih informatif.

c. Sistem dapat mengelola data secara lebih baik dan lebih rapi.

\subsection{Perancangan Sistem}

Perancangan sistem dilakukan dengan merancang diagram UML sesuai dengan kebutuhan sistem yang telah dianalisa, hal ini bisa dilakukan dengan membuat bagan alir sistem, rancangan arsitektur sistem, rancangan use case diagram, class diagram, Sequence diagram, activity diagram, entity relationship diagram, tampilan sistem hingga pengujian sistem.

Aplikasi yang dibangun merupakan Hybrid application sehingga dibuat rancangan arsitektur seperti pada gambar, sistem akan mengakses web server untuk mendapatkan data baik untuk aplikasi yang digunakan user maupun web yang digunakan oleh admin untuk selanjutnya data yang dimasukkan akan disimpan kedalam database server. Pada aplikasi ini, user menggunakan aplikasi yang tersambung dengan internet yang selanjutnya web service akan memberikan ataupun mengambil data dari user. Untuk sisi admin akan menggunakan website yang tersambung dengan internet untuk mengolah semua data.

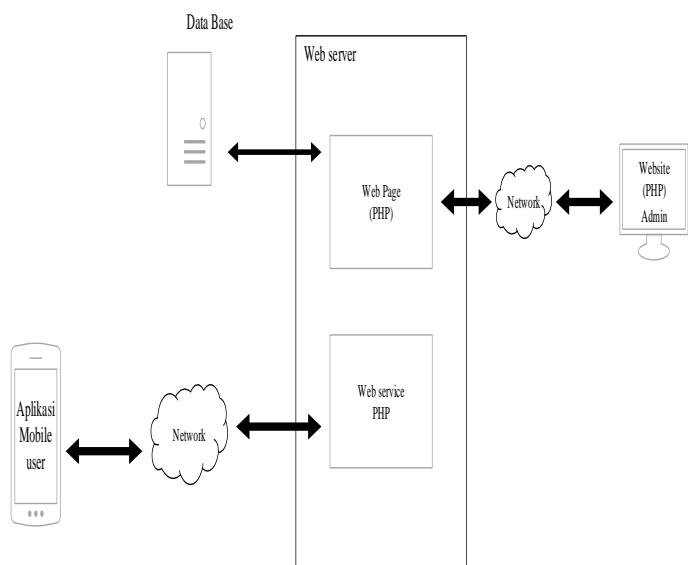

Gambar 2. Arsitektur aplikasi pemesanan kue berbasis mobile.

User dapat melakukan pemesanan kue secara online melalui aplikasi pemesanan kue berbasis mobile android. Use case diagram dari sistem digambarkan pada Gambar 2.

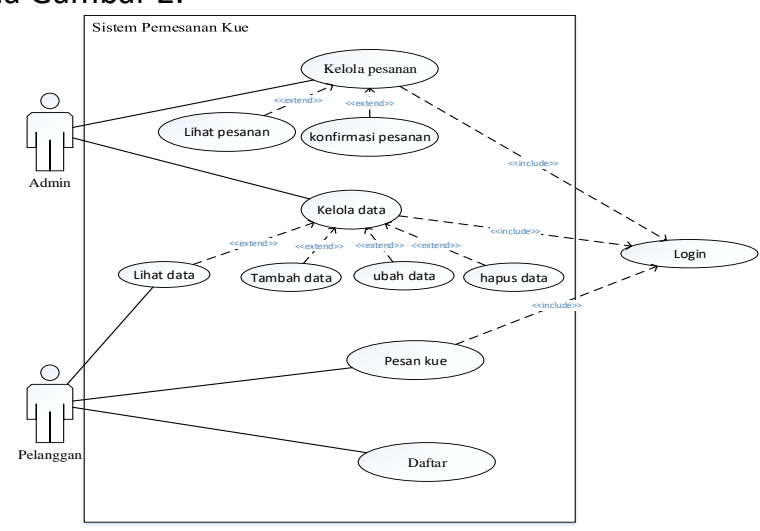

Gambar 3. Use case diagram

Rancangan Entity Relationship diagram pada aplikasi pemesanan kue berbasis mobile pada toko kue Primadona terdapat pada gambar dibawah ini:

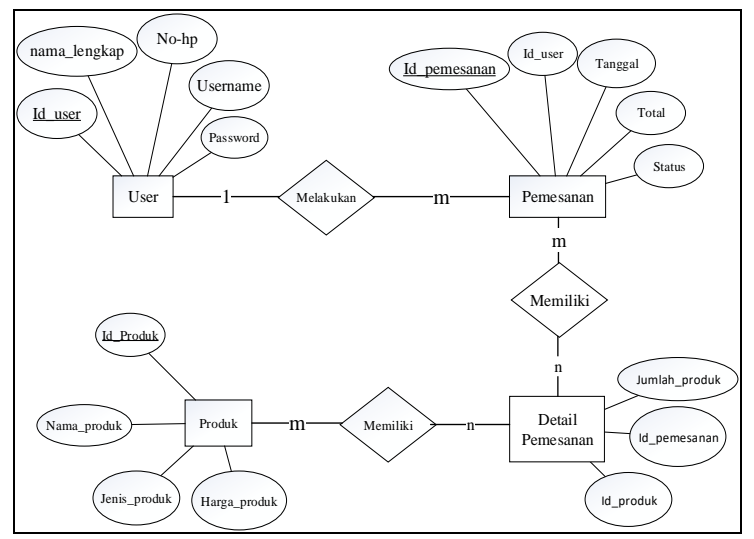

Gambar 4. ER Diagram 
Sedangkan untuk rancangan tabel yang didapatkan beradasarkan turunan ER Diagram yang ada pada Gambar 4. Rancangan tabel user adalah seperti pada Tabel I.

TABEL I. RANCANGAN TABEL USER

\begin{tabular}{|l|l|l|}
\hline Nama kolom & $\begin{array}{l}\text { Tipe } \\
\text { data }\end{array}$ & Ukuran \\
\hline Id_user (PK) & INT & 10 \\
\hline Nama_lengkap & String & 50 \\
\hline No_hp & String & 20 \\
\hline Username & String & 50 \\
\hline Password & String & 50 \\
\hline
\end{tabular}

\section{Hasil dan Pembahasan}

Aplikasi pemesanan kue berbasis mobile dibuat dengan menggunakan framework ionic versi 3 sesuai dengan perancangan aplikasi yang direncanakan, pada bab ini akan dijelaskan teknis pembuatan aplikasi mobile untuk pemesanan kue mulai dari installasi framework, struktur framework, code program, tampilan aplikasi, web service, dan database aplikasi.

a. Code program

Pada framewok ionic sebuah halaman dari aplikasi memiliki dua buah file, yang pertama adalah file dengan format html yang akan menampilkan aplikasi dengan browser sehingga memudahkan pembuat dalam hal pengujian tampilan aplikasi karena lebih cepat dan lebih ringan dibandingkan dengan bahasa pemrograman yang lain.

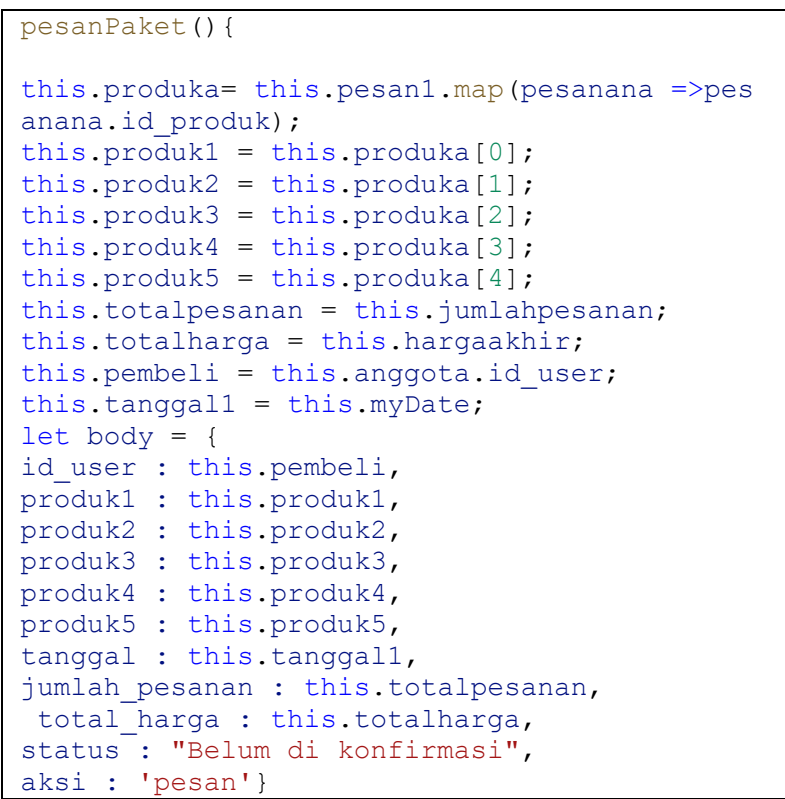

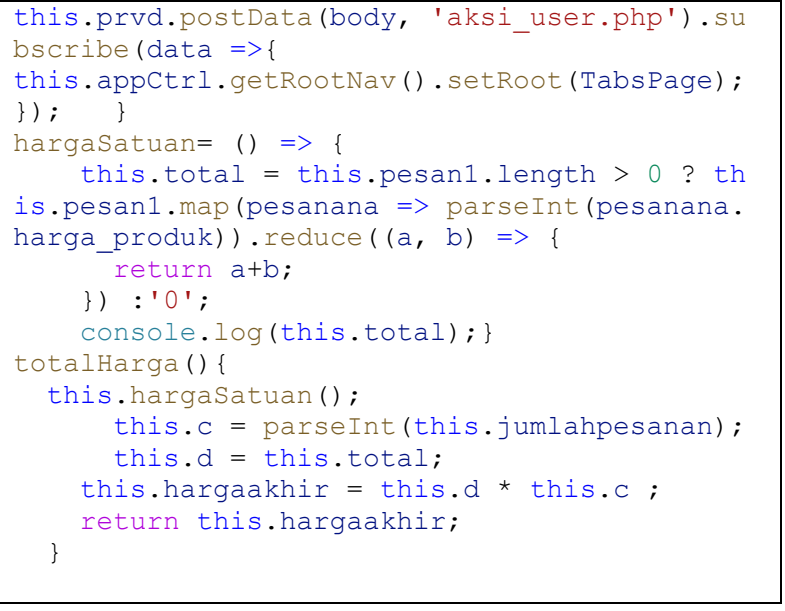

Pada listing program diatas, dijelaskan bagaimana sebuah program untuk memesan paket. Pemesanan paket merupakan salah satu fitur yang dimiliki oleh aplikasi yang dibuat. Pemesanan paket terdiri dari 5 produk yang akan dimasukkan kedalam satu keranjang. Asumsi yang dilakukan adalah, dalam satu kotak kue terdapat 5 macam kue yang akan dipesan. Nama user yang memesan dan total harga akan muncul sesuai dengan siapa yang melakukan pesanan dan berapa total berbelanja.

\section{b. Tampilan User Interface}

Gambar 5 merupakan tampilan dari halaman login aplikasi dan merupakan tampilan awal dari aplikasi karena untuk memesan kue user harus login terlebih dahulu, jika user belum mendaftar sebagai pelanggan, user bisa menekan tombol daftar kemudian akan diarahkan menuju halaman daftar sebagai pelanggan. Pada tampilan ini terdapat field dimana user memasukkan data berupa username dan password. Apabila login sukses maka akan diarahkan kehalaman home namun jika login gagal maka akan muncul pesan login gagal. 


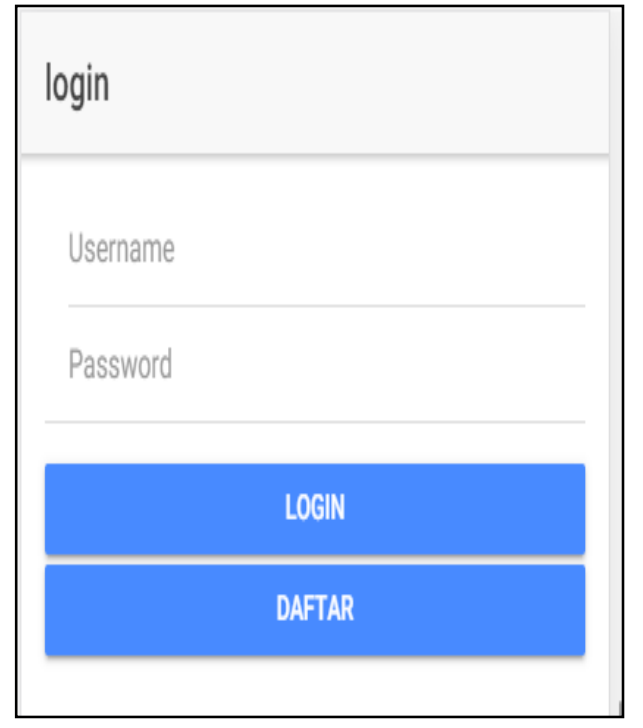

Gambar 5 Tampilan halaman login.

Pada halaman daftar menjadi pelanggan, terdapat beberapa field inputan data user yaitu nomor telepon, nama lengkap, alamat, username dan juga password. Pada halaman ini semua field harus diisi oleh user jika ada yang belum terisi maka akan muncul pesan yang menyatakan bahwa salah satu field masih kosong sehingga harus diisi, selanjutnya user menekan tombol daftar dan jika proses pendaftaran pelanggan berhasil maka tampilan akan diarahkan kembali ke halaman login, tampilan halaman daftar dapat dilihat pada Gambar 6.



Gambar 6 Halaman daftar

Gambar 7 merupakan tampilan utama dari aplikasi pemesanan kue berbasis mobile dimana pada tampilan ini terdapat daftar dari kue yang tersedia pada toko primadona, user dapat memilih beragam kue tersedia untuk dimasukkan kedalam paket yang akan dibeli dengan cara menekan tombol pesan yang terdapat pada masing - masing kue. pada satu kue terdapat keterangan berupa gambar kue, nama kue dan juga harga kue. pada saat user menekan tombol pesan maka secara langsung diarahkan ke halaman keranjang belanja.

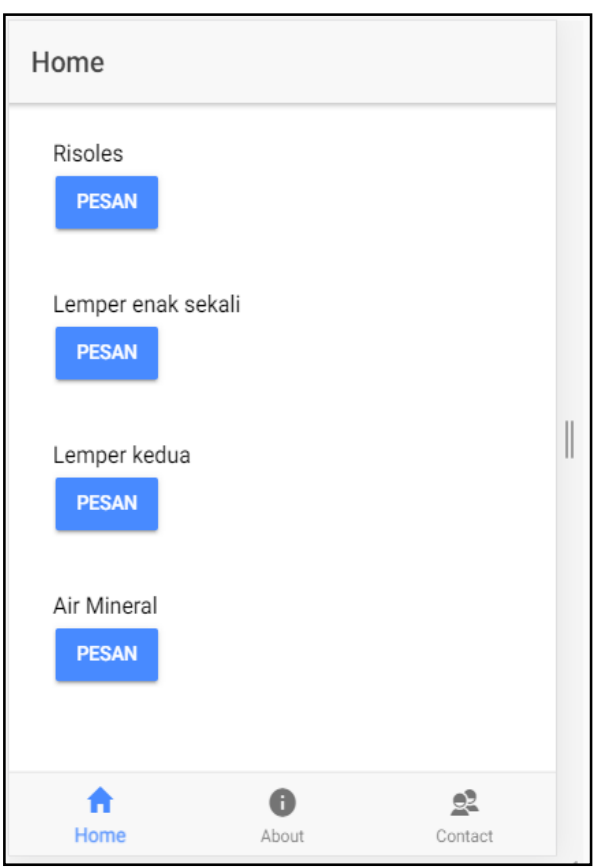

Gambar 7 Halaman Home

Halaman profile merupakan halaman yang menampilkan data dari user yang sedang menggunakan aplikasi pemesanan kue ini, pada halaman ini terdapat tombol setting dan juga tombol logout. Tombol setting akan mengarahkan user jika user ingin mengubah data pada aplikasi maka akan diarahkan ke halaman update. Setelah user menekan tombol logout maka user akan diarahkan ke halaman login namun apabila user menekan tombol home pada handphone maka user tidak perlu login karena data login disimpan dalam session. 


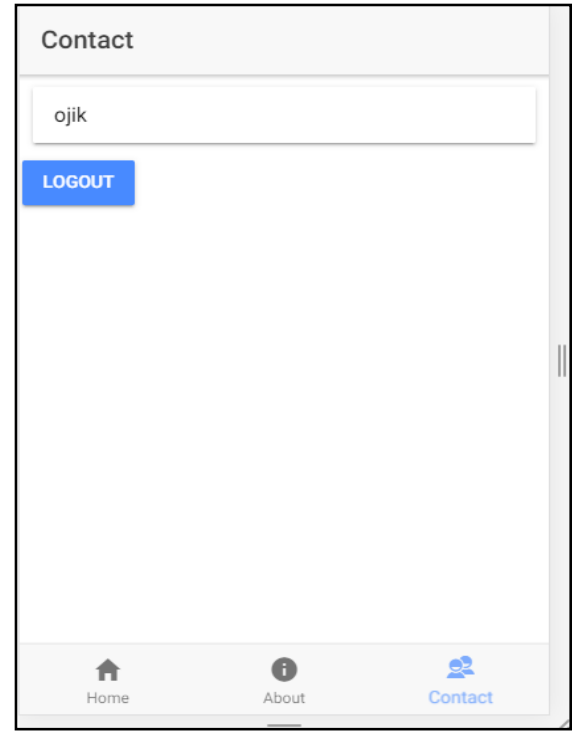

Gambar 8 Halaman profile

c. Pengujian dengan metode Black-box

Hasil pengujian dengan menggunakan black box pada aplikasi pemesanan kue berbasis mobile. Pada fitur login user terdapat dua skenario pengujian, yang pertama adalah login dengan data yang terdapat dalam database user dengan hasil sesuai dengan yang diharapkan kemudian fungsi login dengan salah satu input masih kosong, hasilnya sesuai dengan yang diharapkan hasil pengamatan untuk fitur login dapat dilihat pada Tabel II.

TABEL II. DAFTAR PENGUJIAN YANG DILAKUKAN

\begin{tabular}{|c|c|c|c|}
\hline $\begin{array}{l}\text { Skenario } \\
\text { Pengujian }\end{array}$ & $\begin{array}{c}\text { Yang } \\
\text { diharapkan }\end{array}$ & $\begin{array}{l}\text { Hasil } \\
\text { penga- } \\
\text { matan }\end{array}$ & Kesimpulan \\
\hline $\begin{array}{c}\text { Memasuk } \\
\text { kan data } \\
\text { pada } \\
\text { form } \\
\text { login } \\
\text { dengan } \\
\text { data yang } \\
\text { telah } \\
\text { terdaftar } \\
\text { pada } \\
\text { database. }\end{array}$ & $\begin{array}{c}\text { Menampilkan } \\
\text { pesan login } \\
\text { berhasil dan } \\
\text { menampilkan } \\
\text { halaman } \\
\text { home. }\end{array}$ & Sesuai & Valid \\
\hline $\begin{array}{l}\text { Menekan } \\
\text { tombol } \\
\text { login } \\
\text { dengan } \\
\text { salah satu }\end{array}$ & $\begin{array}{c}\text { Menampilkan } \\
\text { pesan field } \\
\text { tidak boleh }\end{array}$ & Sesuai & Valid \\
\hline $\begin{array}{l}\text { fie/d } \\
\text { http: pika } \\
\text { masih } \\
\text { kosong }\end{array}$ & $\begin{array}{l}\text { kosong }_{\text {fi }} \\
\text { f.unraciacio }\end{array}$ & dex.php/ & TIKA/ \\
\hline
\end{tabular}

Pengujian dilakukan dengan dua skenario pengujian. Pengujian pertama menguji dengan memasukkan data sesuai dengan field daftar yang tersedia dan hasil yang diharapkan adalah menampilkan pesan pendaftaran yang berhasil dan menampilkan halaman login, hasil dari pengujian yang pertama sesuai dengan hasil yang diharapkan. Skenario yang kedua adalah user mencoba mendaftar dengan tidak mengisi salah satu field, hasil yang diharapkan adalah menampilkan pesan bahwa field tidak boleh kosong. Hasil dari pengujian kedua sesuai dengan hasil yang diharapkan. Hasil uji fitur daftar user dapat dilihat pada Tabel III.

TABEL III. HASIL UJI FITUR DAFTAR

\begin{tabular}{|c|c|c|c|}
\hline $\begin{array}{l}\text { Skenario } \\
\text { Pengujian }\end{array}$ & $\begin{array}{c}\text { Yang } \\
\text { diharapkan }\end{array}$ & $\begin{array}{c}\text { Hasil } \\
\text { penga } \\
\text { matan }\end{array}$ & $\begin{array}{c}\text { Kesimpul } \\
\text { an }\end{array}$ \\
\hline $\begin{array}{l}\text { Memasukk } \\
\text { an data } \\
\text { pada form } \\
\text { daftar } \\
\text { sesuai } \\
\text { dengan } \\
\text { dengan } \\
\text { data pada } \\
\text { field. }\end{array}$ & $\begin{array}{c}\text { Menampilkan } \\
\text { pesan } \\
\text { pendaftaran } \\
\text { berhasil dan } \\
\text { menampilkan } \\
\text { halaman login. }\end{array}$ & Sesuai & Valid \\
\hline $\begin{array}{c}\text { Menekan } \\
\text { tombol } \\
\text { daftar } \\
\text { dengan } \\
\text { kondisi } \\
\text { salah satu } \\
\text { field masih } \\
\text { kosong }\end{array}$ & $\begin{array}{l}\text { Menampilkan } \\
\text { pesan field } \\
\text { tidak boleh } \\
\text { kosong. }\end{array}$ & Sesuai & Valid \\
\hline
\end{tabular}
d. Uji Statistik menggunakan MOS (Mean Opinion
Score)

Hasil pengujian dengan menggunakan metode MOS (Mean Opinion Score) dengan memberikan empat pertanyaan kepada 30 orang responden. Adapun bagin yang diukur yaitu tampilan, kemudahan aplikasi dan performa aplikasi. Adapun nilai rata-rata dari setiap pertanyaan dapat dilihat pada Tabel IV. 
TABEL IV. NILAI RATA-RATA PERTANYAAN

\begin{tabular}{|c|c|}
\hline Pertanyaan nomor & Nilai rata-rata \\
\hline 1 & 3,6 \\
\hline 2 & 3,86 \\
\hline 3 & 3,76 \\
\hline 4 & 3,86 \\
\hline
\end{tabular}

Berdasarkan rata-rata dari seluruh nilai pertanyaan maka dapat disimpulkan bahwa aplikasi bernilai cukup baik. Rumus untuk mendapatkan nilai rata-rata nilai MOS adalah sebagai berikut

$$
\begin{aligned}
\text { nilai rata }- \text { rata } & =\sum_{=3,86} \frac{3,76+3,86+3,76+3,86}{4} \\
& =1
\end{aligned}
$$

\section{KESIMPULAN DAN SARAN}

Berdasarkan pembahasan tentang aplikasi pemesanan kue berbasis mobile pada toko primadona terdapat beberapa hal yang dapat disimpulkan adalah sebagai berikut :

1. Berdasarkan pengujian yang dilakukan menggunakan black box semua fitur dalam sistem telah berjalan sesuai dengan rancangan yang dibuat.

2. pengujian dengan MOS menunjukkan bahwa responden menyatakan setuju dengan aplikasi dilihat dari nilai rata-rata dari seluruh pertanyaan yang nilainya 3,85 yang artinya aplikasi memiliki nilai cukup baik.

Terdapat beberapa saran yang perlu disampaikan berdasarkan hasil pembahasan aplikasi pemesanan kue berbasis mobile yaitu :

1. Untuk penelitian selanjutnya, disarankan untuk memperbarui tampilan dari aplikasi sehingga terlihat lebih menarik.

2. Perlunya membuat fitur pesan sehingga user dapat berkomunikasi dengan admin sebelum atapun sesudah melakukan pemesanan.
3. Menambahkan fungsi mengirim password dengan pesan menuju nomor telepon user

\section{DAFTAR PUSTAKa}

[1] A. Mahaseptiviana, "Analisis dan Perancangan Sistem Informasi," Jurnal Sistem Informasi, vol. III, no. 6, p. 2, 2014.

[2] O. R. FAJRIN, "Hubungan Tingkat Penggunaan Teknologi Mobile Gadget," JURNAL IDEA SOCIETA, vol. 2, no. 6, p. 5, 2016.

[3] M. Syani, "Perancangan Aplikasi Pemesanan catering Berbasis Mobile Android," Jurnal IImiah Ilmu dan Teknologi Rekayasa, vol. 1, no. 2, p. 86, 2018.

[4] R. Febriani, "Fonde: Aplikasi Pemesanan Makanan Pada Perangkat Lunak," Prosiding Sentrinov, vol. 001, no. 12, p. 301, 2015.

[5] I. Ade, "Pembuatan Aplikasi Penjualan Kue Kering Berbasis Web (Studi Kasus Industri Rumahan Winda)", Proceeeding of Applied Science, vol.1, no. 1, p.191, 2015

[6] F.R. Ridho, R. Soelistijadi, "Perancangan Aplikasi Pemesanan Makanan Ringan Berbasis Object Oriented dengan Metode Waterfall" , Proceeding SENDI-U, 2019.

[7] M.F. Widad, "Sistem Informasi Penjualan Berbasis Android di Toko Busana Faisal Collection", Skripsi, Program Studi Sistem Informasi Fakultas Teknik dan Ilmu Komputer, Universitas Komputer Indonesia, Bandung, 2017.

[8] M. Shalahuddin, Rekayasa Perangkat Lunak Terstruktur dan Berorientasi Objek, Bandung: Informatika, 2015.

[9] R. Machmud, "Peranan Penerapan Sistem Informasi Manajemen Terhadap Efektifitas Pegawai Lembaga Pemasyarakatan Narkotika (LAPASTIKA bollangi kabupaten Gowa)," Jurnal Capacity STIE AMKOP Makassar, vol. 9, no. 3, p. 410, 2013.

[10] A. A. Huda, Live Coding 9 Aplikasi Android Buatan Sendiri, Yogyakarta: C.V Andi Offset, 2013.

[11] R. Abdulloh, Mudah Membuat Aplikasi Android dengan Ionic 3, Jakarta: PT Elex MediaKomputindo,2018 